\title{
Difference between Engineering Program Accreditations at Baccalaureate and Master's Level: Case Study Based on ABET
}

\author{
https://doi.org/10.3991/ijet.v14i08.10409 \\ Wang Chuanyi ( $\bowtie)$ \\ Tsinghua University, Beijing, China \\ wcy1985@tsinghua. edu.cn \\ Cao Yi \\ Wuhan University, Hubei, China
}

\begin{abstract}
As the education level of engineering and scientific talents continuously rise worldwide, the demand for master engineering program accreditation has gradually increased. International engineering program accreditation organizations mostly focus on baccalaureate level, less on the master's level and above. In order to construct accreditation system of engineering program at master's level, this study selected ABET, one of the pioneers in accreditation at the master's level, as a case study that emphasizes on revealing differences of engineering program accreditations in master's and baccalaureate level. The study found that, compared to the baccalaureate level, the general criteria of master's level is emphatically featured in curriculum accreditation master's level general criteria feature curriculum accreditation criteria that lay more emphasison previous course accumulation, professionalism and practicality, assessment review, higher level faculty, and along with facilities focusing more on student-centered concept and requirement for information society.
\end{abstract}

Keywords-Engineering program accreditations; Master; ABET

\section{Introduction}

In the United Kingdom and the United States, Engineering Programs Accreditation goes through a long history of development. Professional accreditation organizations such as the U.S. Accreditation Board for Engineering and Technology (ABET), the British Engineering Council (ECUK) and German Accreditation Agency for Study Programs in Engineering, Informatics, Natural Sciences and Mathematics (ASIIN) have promoted the development and implementation of a series of global and regional accreditation criteria and evaluation standards in an effort to make engineering program quality gain recognition from international counterparts, ensure that the trained engineering talents obtain world-recognized certificates, and facilitate the international mobility of engineering professionals as well as their employment in the international market. Economic globalization will accelerate the internationalization of engi- 
neering education, so global and regional accreditation has gradually become an indispensable measure to guarantee engineering talent training quality. In 1989, based on respective domestic engineering program accreditation systems, an international mutual recognition agreement (MRA), i.e. "Washington Accord", was signed among the six countries including the United States, Canada, the United Kingdom, Ireland, Australia, and New Zealand to mutually recognize professional accreditation conclusions of the member states. This accord is currently the most authoritative and internationally influential mutual recognition agreement on engineer. [1]

As the education level of engineering and scientific talents continuously rises worldwide, the demand for master engineering program accreditation has gradually increased. The American "2020 Engineer Action Report" suggested that baccalaureate degree should be regarded as a preliminary degree in engineering or a "blank engineer" degree, and that certified master's degree should be viewed as the first-level (program) degree in engineering. It has grown into a trend that professional engineering accreditation extends from baccalaureate level to the master's level. Unfortunately, however, accreditation of "Washington Accord" is limited to the baccalaureate level. A special global engineering program accreditation system has not yet been established at the master's level.

Based on this, this study will make comparative analysis on accreditation criteria at master's and baccalaureate level with ABET, a pioneer of Accreditation of MEng., as a case to refine the main features of engineering program accreditation criteria in master's level.

\section{Research Methods and Conceptual Framework}

Case Study Method is a method of qualitative research. Through a typical case, it describes what the actual phenomenon is and analyzes why it happened as a comprehensive and realistic reflection of objective facts, and discovers or explores general regularity and particularity therein. Case study method is a very appropriate research method when the research object is a phenomenon in the contemporary real environment and when researcher is required not to control or unable to control the research object. Using case studies as a starting point for scientific research can earnestly increase empirical validity.

ABET was selected as a case mainly owing to the following three reasons: (1) ABET has a worldwide influence. ABET made up of signing members of the five international mutual recognition agreements (MRA) including "Engineers Canada", "Washington Accord", "The Seoul Accord", the "Sydney Accord" and "the Dublin Accord" effectively promotes the flow of students and graduates, and accelerates global education cooperation.(2)ABET accreditation body closely relies on the social engineering industry community and has gained approval from governments with high influence and authority. Respectively on behalf of government and social forces, the U.S. Department of Education and non-governmental Council for Higher Education Accreditation (CHEA) recognizes ABET's authority to award degrees to program education of engineering, technology, computer and applied sciences.(3)ABET owns a 
complete accreditation system of engineering program, which is an institution with an earlier start in engineering accreditation at master's level. It develops detailed criteria for accrediting engineering programs, including general criteria and program criteria. According to an ABET-Accredited program report, there are a total of 42 engineering accreditations at master's level during 2015-2016[2], of which 16 universities are certified by ABET at both baccalaureate and master's levels (Table 1).

Table 1. Universities certified by ABET atboth baccalaureate and master's levels

\begin{tabular}{|c|c|c|}
\hline University & Baccalaureate level program & Master's level program \\
\hline City University of New York & Engineering Science(S), BS & $\begin{array}{l}\text { Environmental and Occupational } \\
\text { Health Science, MS }\end{array}$ \\
\hline Colorado State University & Engineering Science(S), BS & Health Physics, MS \\
\hline East Carolina University & Engineering, BS & Occupational Safety, MS \\
\hline $\begin{array}{l}\text { Lawrence Technological Universi- } \\
\text { ty }\end{array}$ & Civil Engineering, BS & Architectural Engineering, MS \\
\hline Manhattan College & Civil Engineering, BS & Environmental Engineering, ME \\
\hline $\begin{array}{l}\text { Montana Tech of the University of } \\
\text { Montana }\end{array}$ & Computer Science, BS & Industrial Hygiene, MS \\
\hline Murray State University & $\begin{array}{l}\text { Occupational Safety and Health, } \\
\text { BS }\end{array}$ & Occupational Safety and Health, MS \\
\hline $\begin{array}{l}\text { Purdue University at West Lafa- } \\
\text { yette }\end{array}$ & Nuclear Engineering, BS & $\begin{array}{l}\text { Occupational and Environmental } \\
\text { Health Sciences, MS }\end{array}$ \\
\hline Texas Tech University & Civil Engineering, BS & Environmental Engineering, MS \\
\hline The Johns Hopkins University & Civil Engineering, BS & Systems Engineering, MSE \\
\hline $\begin{array}{l}\text { University of Minnesota - Twin } \\
\text { Cities }\end{array}$ & Civil Engineering, $\mathrm{BCE}$ & Industrial Hygiene, MS \\
\hline West Virginia University & Computer Engineering, BS & Industrial Hygiene, MS \\
\hline University of Central Missouri & $\begin{array}{l}\text { Occupational Safety and Health, } \\
\text { BS }\end{array}$ & Industrial Hygiene, MS \\
\hline Idaho State University & Health Physics, BS & Health Physics, MS \\
\hline
\end{tabular}

BS: (Bachelor of Science) ; MS: (Master of Science) ; BCE (Bachelor of Civil Engineering) MSE (Master of Systems Engineering)

ABET considers the consistency and difference of accreditation criteria at baccalaureate and master's level from the perspective of accreditation criteria system. The two levels share the different programs criteria in view of particularity of different programs, including specific learning outcomes, curriculum themes and teacher qualifications. Some special types of program faculties need specific expertise and certain qualifications, and should meet specific professional demands to give courses or lectures in this field. In the ABET 2017-2018 criteria for accrediting engineering programs, 28 programs in engineering accreditation criteria set corresponding professional criteria for different programs[3]. Due to the great differences in programs criteria, this study focuses only on similarities and differences of general criteria at the master's and baccalaureate level, as shown in Figure 1. 


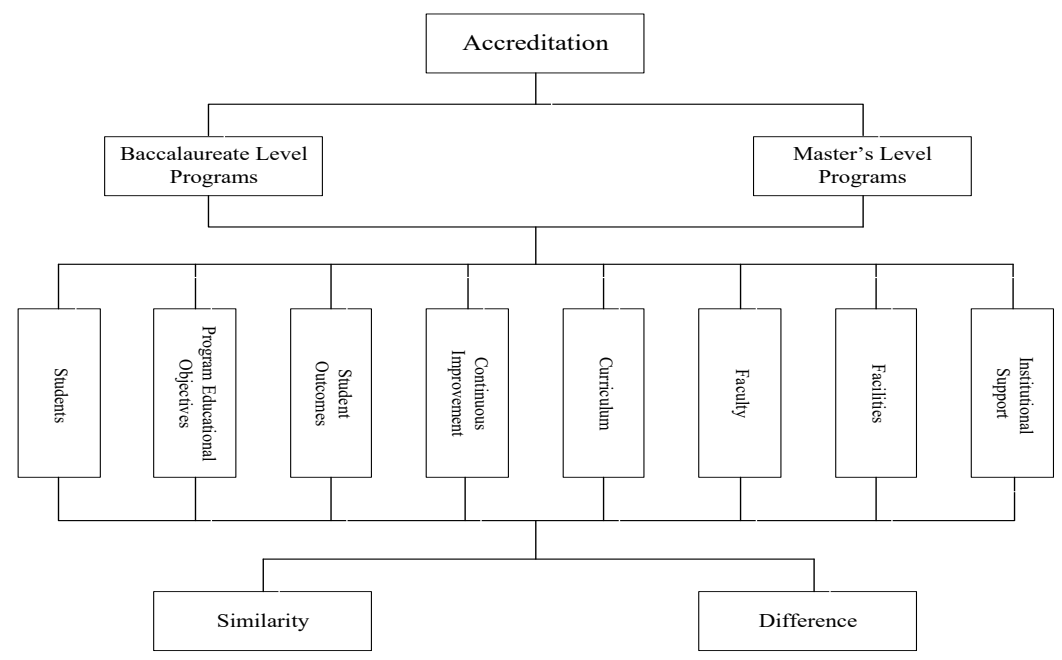

Fig. 1. Conceptual Frame work of General Criteria by level

\section{Similarity of General Criteria between Baccalaureate and Master's Level}

General criteria for engineering program accreditation have the same framework at master's and baccalaureate level in overall, which fall in a general criteria system consisting of 8 indexes of Students, Program Educational Objectives, Student Outcomes, Continuous Improvement, Curriculum, Faculty, Facilities, and Institutional Support[4-5]. (Table 2)

Table 2. General criteria at Master's and Baccalaureate Level

\begin{tabular}{|c|c|}
\hline $\begin{array}{c}\text { General } \\
\text { criteria }\end{array}$ & $\begin{array}{c}\text { Common key points in general criteria for accreditation at baccalaureate, } \\
\text { master's level }\end{array}$ \\
\hline Students & $\begin{array}{l}\text { guide, evaluate, and test the students' academic level to ensure graduation criteria are } \\
\text { met }\end{array}$ \\
\hline bjec & $\begin{array}{l}\text { Definite program educational objectives, including academic and skills, communica- } \\
\text { tion, etc., with corresponding evaluation criteria }\end{array}$ \\
\hline Student Outcomes & $\begin{array}{l}\text { Evaluation of input and output, i.e. whether the students' learning outcomes meet the } \\
\text { program output, graduation requirements, employers' expectations }\end{array}$ \\
\hline $\begin{array}{l}\text { Continuous Im- } \\
\text { provement }\end{array}$ & $\begin{array}{l}\text { Master the student's learning dynamics based on certain procedures and support } \\
\text { follow-up learning improvement on this basis. }\end{array}$ \\
\hline Curriculum & $\begin{array}{l}\text { The subject area and curriculum system should be suitable for the cultivation of } \\
\text { engineering talents to prepare them for engineering careers }\end{array}$ \\
\hline Faculty & $\begin{array}{l}\text { ave appropriate qualifications and } \\
\text { ge between teachers and students. }\end{array}$ \\
\hline Facilities & $\begin{array}{l}\text { Classrooms, laboratories and equipment, atmosphere and other facilities for special } \\
\text { subject education }\end{array}$ \\
\hline Institutional Support & $\begin{array}{l}\text { Appropriate school support, financial resources and constructive leadership, adequate } \\
\text { resources to ensure engineering program quality and continuity }\end{array}$ \\
\hline
\end{tabular}


Through the lens of criteria of Curriculum, Faculty and Facilities, it could be found that general criteria at the master's and baccalaureate level all have shared items more or less.

The curriculum requirements have three shared items at the baccalaureate and master's level: basic science courses (college mathematics, basic science), engineering program courses (program courses of engineering theory and practice) and designrelated engineering practice [6]. The general criteria for curriculum require that: "one year of a combination of college level mathematics and basic sciences appropriate to the discipline; one and one-half years of engineering topics, consisting of engineering sciences and engineering design appropriate to the student's field of study. Students must be prepared for engineering practice through a curriculum culminating in a major design experience based on the knowledge and skills acquired in earlier course work and incorporating appropriate engineering standards and multiple realistic constraints." [7]

The faculty requirements have four shared items at the baccalaureate and master level: in terms of faculty size, both require sufficient number of program faculty and a reasonable student-teacher ratio to ensure that there is sufficient faculty for teacherstudent interactions and exchange with social workers, etc.; in terms of faculty quality criteria, both require that program teachers are competent in the respective curriculum covering all program courses; in terms of faculty rights and liabilities, both require that teachers should obtain necessary teaching qualifications while enjoying full authority to ensure undertaking of normal program teaching activities; in terms of faculty evaluation criteria, both recognize that faculty's overall ability can be comprehensively accessed via multiple qualitative and quantitative indicators including the following categories: academic qualification (degrees, education levels, professional academic level, experience of studying abroad, etc.), personalization indicators(personal background, participation in professional societies and licenses, diversification qualifications, etc.), professional indicators(engineering practices, engineering teaching, engineering, engineering education history etc.), teaching-oriented indicators(teaching effect, teaching experience, education level, etc.), integrated indicators (expression skills, communication skills, etc.).

Basic conditions for students' learning, adequacy of classrooms, laboratories, and related facilities are necessary facilities requirements for the training objectives. Therefore, accreditations at baccalaureate and master's levels require that teaching facilities should include such site infrastructure conditions as classrooms, offices, laboratories, libraries to provide an effective learning atmosphere, adequate (and safe) facilities, modern engineering tools for student learning to achieve program objectives and educational outcomes; support academic activities for teachers and students; encourage professional development and professional activities; offer opportunities to use advanced engineering tools. Relevant requirements are made for school facilities that library services, computers and information infrastructure should be offered. There should be ample resources to attract and maintain high level faculty, and provide them with industry-competitive career development opportunities [8].There should be sufficient resources for obtaining, maintaining and operating the required facilities.[9] 


\section{Differences of General Criteria between Master's and Baccalaureate Level}

Although general criteria for engineering accreditation shares the same framework at the master's and baccalaureate level, accreditation criteria at the master's level represents an extension and elevation of that at the baccalaureate level. In addition to the above eight general criteria, one more criterion is required for master level program quality. The criteria requirements are prescribed as follows: "The master's level engineering program must have a documented and operational process for assessing, maintaining and enhancing the quality of the program." Moreover, the differences are mainly reflected in the following three aspects: Curriculum, faculty and facilities.

\subsection{Curriculum}

As baccalaureate and master's levels are dedicated to cultivating different types of talents, some significant differences are shown in depth and emphasis of curriculum accreditation criteria. The accreditation at the master's level is mainly reflected in the following aspects:

Emphasis on students' previous curriculum learning experience: The curriculum accreditation criteria at master's level are more layered based on students' previous curriculum learning experience. Since master training quality is closely related to basic knowledge acquired at the baccalaureate level, students' previous program learning will affect the training objective at the master's level.[10] Therefore, layered criteria requirements are set for master's level curriculum according to students' different curriculum learning experiences. The master's level curriculum criteria requirements are made for two types of students. The first type of students, non-ABET certified EAC graduates, should meet two requirements:

1. Supports the attainment of student outcomes of corresponding criterion at baccalaureate level

2. Includes at least one year of math and basic science (basic science includes the biological, chemical, and physical sciences), as well as at least one-and-one-half years of engineering topics and a major design experience that meets the requirements of corresponding criterion at baccalaureate level.

If the student has graduated from an EAC of ABET accredited baccalaureate program, the presumption is that items 1 and 2 above have been satisfied.

Focus on the specialty of curriculum study: Master-level curriculum criteria require at least one year of mathematics and basic science study, and at least one-and-ahalf year of engineering program study on the basis of baccalaureate level study. The required curriculum duration is longer in master's level (at least one year or one and a half years' study) than in baccalaureate level (one year or one and a half years' study). In addition, further study of at least 30 hours is required for engineering curriculum of master's programs (or equivalent education) on the basis of baccalaureate curriculum. 
The master-level curriculum criteria require that: Each student's overall program of post-secondary study must satisfy the curricular components of the baccalaureate level program criteria relevant to the master's level program name. The master's level engineering program of study must require the completion of at least 30 hours (or equivalent) beyond the baccalaureate program.

Due to the greater professionalism, the master's level curriculum criteria lack the criteria requirement of baccalaureate level for general education courses (general knowledge in all fields related to practical engineering problems), and weaken the extensive learning of social and humanistic knowledge. Thus, more emphasis on teaching of program curriculum knowledge is inevitable, as demonstrated in more emphasis of master program accreditation on curriculum specialty. While, baccalaureate criteria require that: "a general education component that complements the technical content of the curriculum and is consistent with the program and institution objectives."

Emphasis on engineering practice of program: Compared to baccalaureate lev$\mathrm{el}$, the master's level engineering practice requires that each student has the program internship or practice in consistency with the master's degree program and reaches the level beyond the minimum requirements of baccalaureate degree program. In addition, the master's level curriculum criteria emphasize the consistency and continuity of curriculum program, requiring that students' college-level curriculum must meet curriculum requirements for baccalaureate programs with curriculum name related to that of master programs. The program practice at the baccalaureate level is only achieved through practical courses, while engineering practice at the master's level is derived from actual projects and practical projects of external partners such as companies, research institutes, etc., Compared to the practice of baccalaureate level, the latter enables students to improve their program practice knowledge and skills while continuously accumulating abundant complex and real engineering practice experiences. The master-level curriculum criteria require that: "The master's level engineering program must require each student to demonstrate a mastery of a specific field of study or area of professional practice consistent with the master's program name and at a level beyond the minimum requirements of baccalaureate level programs."

Focus on review of the curriculum assessment process: The master-level curriculum criteria are added with supervision and evaluation of students' academic performance and study plan completion, which has standardized and quantified curriculum requirements for masters in stages. The procedural assessment reflects the continuous improvement idea in master-level curriculum evaluation. Corresponding supervision and evaluation measures are set for all aspects of curriculum planning, setting, management and implementation. Through comprehensive evaluation procedures, attention is paid to various links of curriculum implementation to achieve continuous selfdevelopment and improvement of the curriculum. The master-level curriculum criteria require that: "The master's level engineering program must have and enforce policies and procedures ensuring that a program of study with specific educational goals is developed for each student. Student performance and progress toward completion of their programs of study must be monitored and evaluated. The program must have and 
enforce procedures to ensure and document that students who graduate meet all graduation requirements."

\section{2 $\quad$ Faculty}

The faculty criteria is significantly higher for master programs as compared to baccalaureate ones. Teachers own certain engineering education and practice experience, effectively combining scientific research results with teaching practice, timely adjusting and updating lecture contents according to discipline development trends, updating engineering knowledge, enriching engineering practice experience,developing engineering practice ability, improving teaching quality, thus providing guarantee for training students' engineering ability.

First, the master-level faculty criteria require that: "The master's level engineering program faculty must have appropriate qualifications and must have and demonstrate sufficient authority to ensure the proper guidance of the program."

Secondly, the master-level assessment indicators for teachers are more targeted at program and practice, which adjusts the baccalaureate level requirements for teachers "program enthusiasm" to "corresponding educational qualifications or experience", revealing master' $\mathrm{s}$ level curriculum emphasis on combination of theory with practice, as well as assessment of scientific research and practical ability. The master-level faculty criteria require that: "The master's level engineering program faculty must have appropriate qualifications and must have and demonstrate sufficient authority to ensure the proper guidance of the program. The overall competence of the faculty may be judged by such factors as education, diversity of backgrounds, engineering experience, teaching effectiveness and experience, ability to communicate, level of scholarship, participation in professional societies, and licensure."

\subsection{Facilities}

In addition, master's level program dedicated to cultivation of higher-level engineering professionals has higher requirements for facilities accreditation as demonstrated in the following aspects:

Listening to students' voices and expanding learning space: The master's level program attaches great importance to the combination of teaching and scientific research, and highlights students' independent exploration and active research capability. Its requirements for program facilities are no longer confined to traditional teaching sites like classrooms, offices, and laboratories, but emphasize that all student communication-related channels shall provide students with learning atmosphere. It lays more emphasis on listening to students' voices, emphasizing teacher-student interaction, implementing "full-process" cultivation of engineering students, promoting personalized development to foster extraordinary engineering talents capable of solving complex engineering problems. At the same time, student learning space and scope are fully extended, multiple learning and communication channels are utilized to ensure that master students more freely study and solve engineering problems, and then learn and communicate more actively. The master-level facilities criteria require 
that Means of communication with students, and student access to laboratory and other facilities, must be adequate to support student success in the program, and to provide an atmosphere conducive to learning.

Providing professional and practical supporting equipment: The school facilities criteria emphasize that resources and teaching facilities provided by the school must reflect the most cutting-edge professionalism and practicality in the discipline, and demonstrate the integration of teaching facilities and disciplinary characteristics. On the one hand, teaching equipment includes computer and information infrastructure, library service software systems to maintain the timely update of frontier scientific research achievements in the program, better help engineering students understand and master knowledge of contemporary social and science and technology hotspot issues, update disciplinary expertise, and improve frontier knowledge framework of the discipline. On the other hand, modern teaching tools, teaching equipment, and laboratories resources reflect practical requirements of the discipline, and highlight the combination of theory and practice as well as the integration of teaching and research in the master program as compared to baccalaureate program, which helps engineering students comprehensively use technology and skills. The master-level facilities criteria require that: "These resources and facilities must be representative of current professional practice in the discipline."

Combining online and offline modes: Compared with baccalaureate program, master program requires the combination of online and offline teaching and scientific research mode in terms of accreditation of school facilities. It requires additional online, remote, and virtual learning facilities to laboratory and other teaching equipment resources so that teachers will not occupy excessive classroom time to lecture the basic course content, curriculum teaching can be completed independently by students using multiple contemporary teaching equipment through teaching videos, electronic reading books, web-based discussion, which saves a lot of time for master program training emphasizing specialty and practice. Through full exposure to modern education training, utilization of the latest methods and technologies, sufficient international and domestic academic exchanges, master students can better focus on active project-based learning, jointly study and solve engineering design issues, and thus gain a deeper understanding. Meanwhile, teachers can also have more time to communicate with students and give personalized instruction to ensure the combination of teaching and research. The master-level facilities criteria require that: "Remote or virtual access to laboratories and other resources may be employed in place of physical access when such access enables accomplishment of the program's educational activities."

Providing service-oriented training: Compared with baccalaureate program, master program empowers students with the right to acquire and enjoy relevant training suitable for their learning resource in terms of accreditation requirements for school facilities. By providing targeted assistance and necessary training activities for students to effectively use teaching facilities, schools can better popularize and encourage utilization of school teaching facilities among students to actively explore cutting-edge disciplinary knowledge. Through the service-oriented training activities based on the school's corresponding experimental equipment or teaching facilities, 
students' efficiency in using teaching resources can be improved, master students' ability to analyze and solve problems, as well as spirit of criticism and creation can be fostered. The master-level facilities criteria require that: "Students must have access to appropriate training regarding the use of the resources available to them."

\section{Conclusion}

Comparative analysis of the differences between general criteria for accrediting engineering program at baccalaureate and master's level reveals several characteristics of master program.

First, master program serves as the extension and elevation of baccalaureate one. The corresponding requirements for baccalaureate level accreditation should be metfirst, including basic training requirements of the curriculum system, faculty quality and scale, facilities practicality and other basic supportive requirements. Besides, the curriculum system at master's level incorporate the basic engineering facts, concepts, theories and principles, prove that students have the necessary professional knowledge[11], as well as the ability to understand program-related multidisciplinary engineering background and principles; the supporting faculty construction should feature progressive depth in level so that program teachers can instruct students to use appropriate and scientific engineering tools to analyze problems and develop students' creative capabilities in comprehensively solving complex issues.

Second, with the scale expansion of master education, a master's degree has become the minimum certificate for entering the engineering industry. Compared with undergraduates, master students' competitiveness in the labor market should be more reflected in in-depth practicality. The engineering practice skills required for master program are an embodiment of universal transfer skills. By setting clear requirements for engineering practice capabilities, the value of engineering practice is further clarified. On the precondition of guaranteeing broad knowledge scope of engineering masters, engineering practice and design advantages are emphasized, which thus enables clear differentiation between master and baccalaureate program.

Third, compared with undergraduate students, master students have more time for independent study and communication. Some of them learn by work-study-program, so various modern information education technologies are needed to satisfy their learning needs at anytime, anywhere [12]. Master program attaches great importance to the combination of teaching and scientific research, highlighting students' independent exploration and active research capabilities. Information-based education technology can maximally provide master students with project-based learning opportunities, and help them efficiently study and solve complex engineering issues.

\section{Acknowledgement}

Project supported by the Ministry of Education of Humanities and Social Science Fund (16JDGC014) 


\section{$7 \quad$ References}

[1] Accreditation Board for Engineering and Technology, "Mutual Recognition Agreements". Accreditation Board for Engineering and Technology, Engineering: Washington Accord , 2011. [Online]. Available: http://www.abet.org/global-presence/ mutual-recognitionagreements/. [Accessed: Nov. 12, 2017].

[2] Accreditation Board for Engineering and Technology, "Program Search Results". Accreditation Board for Engineering and Technology, Program Search Results , 2016. Available: http://main.abet.org /aps/Accreditedprogramsearch.aspx. [Accessed: Nov. 10, 2017].

[3] Accreditation Board for Engineering and Technology, "2017-2018 Criteria for Accrediting Applied and Natural Science Programs", Accreditation Board for Engineering and Technology, R001-17-18-ASAC-Criteria-10-29-16-1, 2016.

Available: http://www.abet.org/wp-content/uploads/2016/12/R001-17-18-ASAC-Criteria10-29-16-1.pdf. [Accessed: Oct. 29, 2016].

[4] Accreditation Board for Engineering and Technology, Accreditation Policy and Procedure Manual (APPM) 2017-2018. Accreditation Board for Engineering and Technology, 2016.

[5] Lang C R, Gurocak H. Assessment methods for the upcoming ABET accreditation criteria for computer science programs[C]// Frontiers in Education Conference, 2008. Fie 2008. IEEE, 2008:S4G-6 - S4G-11. https://doi.org/10.1109/FIE.2008.4720324

[6] Accreditation Board for Engineering and Technology, "2017-2018 Criteria for Accrediting Engineering Programs", Accreditation Board for Engineering and Technology, E001-17-18-EAC-Criteria-10-29-16-1,2016. Available: http://www. abet.org/wpcontent/uploads/ 2016/12/E001-17-18-EAC-Criteria-10-29-16-1.pdf. [Accessed: Oct. 29, 2016].

[7] Honor J. Passow Ph.D. P.E. Which ABET Competencies Do Engineering Graduates Find Most Important in their Work?[J]. Journal of Engineering Education, 2012, 101(1):95118. https://doi.org/10.1002/j.2168-9830.2012.tb00043.x

[8] Vlasses P H, Wadelin J W, Travlos D V. Accreditation Council for Pharmacy Education: Annual Report[J]. American Journal of Pharmaceutical Education, 2012, 76(8):45.

[9] Batalden P, Leach D, Swing S, et al. General competencies and accreditation in graduate medical education.[J]. Health Affairs, 2002, 21(5):103.

[10] Agboola O P, Hashemipour M, Egelioglu F, et al. Assessing a Decade Old Capstone Senior Projects Through ABET Accreditation Program Outcomes [J]. Procedia - Social and Behavioral Sciences, 2012, 47(1):120-125. https://doi.org/10.1016/j.sbspro.2012.06.624

[11] Lattuca L R, Terenzini P T, Volkwein J F. Panel Session - Engineering Change: Findings from a Study of the Impact of EC2000[C]// Frontiers in Education Conference. IEEE, 2007:1-2.

[12] Parsons C K, Caylor E, Simmons H S. Cooperative Education Work Assignments: The Role of Organizational and Individual Factors in Enhancing ABET Competencies and Coop Workplace Well-Being [J]. Journal of Engineering Education, 2005, 94(3):309-318. https://doi.org/10.1002/j.2168-9830.2005.tb00855.x 


\section{Authors}

Wang Chuanyi is an associate professor in institute of educational sciences $\mathrm{Wu}-$ han University. His research interest including higher education and education assessment.

Cao Yi is a master student in institute of educational sciences Wuhan University.

Article submitted 2019-01-14. Resubmitted 2019-03-07. Final acceptance 2019-03-21. Final version published as submitted by the authors. 